\title{
DOI https://doi.org/10.30525/978-9934-26-041-4-68
}

\section{ТЕХНОЛОГІЯ КРИТИЧНОГО МИСЛЕННЯ У РОБОТІ ВЧИТЕЛЯ ПОЧАТКОВОЇ ШКОЛИ}

\author{
Демченко Н. М. \\ кандидат педагогічних наук, \\ дочент кафедри педагогіки, початкової освіти \\ та освітнього менеджменту \\ Ніжинський держсавний університет імені Миколи Гоголя \\ Білоусова Н. В. \\ кандидат педагогічних наук, \\ дочент кафедри педагогіки, початкової освіти \\ та освітнього менеджменту \\ Ніжинський державний університет імені Миколи Гоголя
}

Гордієнко Т. В.

кандидат педагогічних наук,

доцент кафедри педагогіки, початкової освіти

та освітнього менеджменту

Ніжинський державний університет імені Миколи Гоголя м. Ніжин, Чернігівська область, Україна

Метою «Концепції реалізації державної політики у сфері реформування загальної середньої освіти «Нова українська школа» на період до 2029 року» $€$ забезпечення здійснення системного реформування загальної середньої освіти за такими провідними напрямами як ухвалення державних стандартів, що враховують компетентності, необхідні для успішної самореалізації особистості; запровадження нових принципів педагогіки партнерства та дитиноцентризму; а випускник Нової української школи - це всебічно розвинена особистість, здатна до критичного мислення; інноватор, здатний змінювати навколишній світ, розвивати економіку за принципами сталого розвитку, конкурувати на ринку праці, навчатися впродовж життя [4]. Водночас дослідження теорії i практики початкової освіти на сучасному етапі реформування системи освіти України доводять, що існує об'єктивна необхідність подолання суперечності між низьким рівнем критичного мислення випускників 
школи та соціальним замовленням суспільства на творчу, критично мислячу особистість, яка спроможна гнучко адаптуватись у потоці інформації, який змінюється швидкими темпами.

Серед напрямків дослідження проблеми критичного мислення у сучасних наукових працях необхідно відзначити такі як: теоретичні засади критичність мислення (К. Баханова, С. Терно, О. Тяглороль); критичності в самостійній творчій діяльності (В. Біблер, Л. Григорович, П. Кравчук); шляхи формування в учнів критичності мислення й ознаки такого мислення як психологічного утворення (Г. Липкіна, Л. Рибак, Н. Чернега); технології формування критичного мислення в учнів початкової школи присвячені роботи В. Гусєва, С. Луців, О. Ю. Саєнко.

Мета статті - визначити місце технології критичного мислення у роботі вчителя початкової школи.

Так, О. Бєлкіна-Ковальчук критичне мислення розглядає як «окремий тип мислення, який характеризується активністю, цілеспрямованістю, самостійністю, дисциплінованістю та рефлективністю та передбачає розвиток у процесі навчання здатності людини: визначати проблеми, аналізувати, синтезувати, оцінювати інформацію з будь-яких джерел, висувати альтернативи й оцінювати їх, обирати спосіб розв'язання проблеми чи власну позицію щодо неї й обгрунтовувати свої погляди, робити свідомий вибір і діяти» [1].

Ю. Саєнко зазначає, що технологія «Критичного мислення» $\epsilon$ системою методичних прийомів, призначених для використання їх в різних освітніх галузях, видах i формах навчання. Ця технологія дозволяє сформувати такі вміння як працювати 3 інформаційним потоком, який постійно оновлюється, вміння ясно та чітко висловлювати свої думки, впевнено та коректно по відношенню до оточуючих; вміння обгрунтовувати власну думку на основі осмислення різного досвіду, ідей та уявлень; вміння вирішувати проблеми; здатність самонавчання (академічна мобільність); вміння співпрацювати та працювати в групі; здатність вибудовувати конструктивні взаємини з іншими людьми [5, с. 641].

До ключових етапів реалізації технології дослідники відносять: «1. Виклик. Мета - формування особистого інтересу для отримання інформації. Учні мають подумати та розповісти іншим (за допомогою індивідуальної, парної, групової роботи; брейнстормінгу; спільних прогнозувань; озвучування проблемних питань тощо) про те, що вони знають з обраної теми для обговорення - так отримані раніше знання усвідомлюються та стають базою для засвоєння нових. Задача вчителя на цьому етапі - узагальнити знання дітей, допомогти кожному визначити «своє знання» й основні цілі для отримання нових. 
2. Осмислення. Діти знайомляться з новою інформацією. При цьому вони мають відслідкувати своє розуміння й записувати у формі питань те, що вони не зрозуміли - для того, щоб пізніше заповнити ці «білі плями». Після ознайомлення з інформацією кожен учень має сказати про те, які орієнтири/фрази/слова допомогли йому зрозуміти інформацію, а які, навпаки, заплутували. Головний принцип етапу осмислення - учитель має давати учням право/установку на індивідуальні пошуки інформації з подальшим груповим обговоренням та аналізом. 3. Рефлексія. Учні мають обдумати те, чого вони дізналися та як включити нові поняття у свої уявлення; обговорити, як це змінило їхні думки, бачення, поведінку» [6, с. 14].

Аналіз сучасних психолого-педагогічних досліджень 3 проблеми застосування технології критичного мислення, на уроках в початковій школі дає підстави стверджувати, що вчені виділяють три пріоритетні умови побудови такого уроку: 1) пріоритет індивідуальності (визнання учня як головного учасника освітнього процесу, самодостатнього та особистісно значущого суб'єктивного досвіду); 2) варіативність (передбачає таку позицію вчителя за якої забезпечена можливість індивідуальної самореалізації у навчанні кожного учня); 3) відкритість (передбачає використання вчителем на уроці різноманітних видів навчання; сумісний пошук істини).

С. Луців висвітлює проблему формування критичного мислення учнів початкових класів стверджує, що використання елементів технології розвитку критичного мислення повинно грунтуватися на системі психолого-педагогічних та дидактичних умов. До дидактичних умов автор відносить: 1) урахування індивідуальних та вікових особливостей учнів у способах організації їх діяльності на уроках; 2) гармонізацію емоційного й інтелектуального факторів навчання; 3) проблематизацію змісту навчального матеріалу; 4) забезпечення взаємозв'язку урочної та позаурочної роботи з навчального предмета у початкових класах [2].

Психолого-педагогічні умови формування критичного мислення молодших школярів під час вивчення іноземних мов розглядає О. Мисечко. Так, до психологічних умов оптимізації цього процесу дослідник відносить: по-перше, уміле інформаційне мотивування діяльності завдяки новизні та евристичності матеріалу, який підлягає осмисленню; по-друге, переконливість аргументування, оскільки критично мисляча людини усвідомлює, що існують й інші варіанти вирішення певної проблеми і старається довести, що обране нею рішення є достатньо логічним і раціональним; по-третє, важливо досягати усвідомлення дітьми власної позиції на стільки, щоб вони 40 
могли піддати сумніву як власну аргументацію, так і аргументи інших сторін. Таким чином забезпечується гнучкість мислення [3].

Висновки. Отже, освітня технологія «Критичного мислення» допомагає формуванню в учнів початкової школи: освітньої мотивації (зростання інтересу до процесу навчання та перехід до активного сприйняття навчального матеріалу); інформаційної грамотності (розвиток здатності самостійно аналізувати та оцінювати інформацію різного рівня складності); культури мовлення (формування навичок створення різножанрових текстів); соціальної компетентності (формування комунікативних навичок та відповідальність за отримання знань).

\section{Література:}

1. Бєлкіна-Ковальчук О. В. Формування критичного мислення учнів початкових класів у процесі навчання : автореф. ди с. на здоб. наук. ступ. канд. пед. наук : 13.00 .09 - теорія навчання. Волинський держ. ун-т ім. Л. Українки. Луцьк, 2006. 21 с.

2. Луців С. Педагогічні умови формування критичного мислення учнів початкових класів на уроках української мови. Актуальні питання гуманітарних наук. 2016. Bun. 16. С. 347-352. URL : http://nbuv.gov.ua/UJRN/apgnd_2016_16_45.

3. Мисечко О. Є. Психолого-педагогічні умови формування критичного мислення молодших школярів при вивченні іноземних мов. URL : http://eprints.zu.edu.

4. Про схвалення Концепції реалізації державної політики у сфері реформування загальної середньої освіти «Нова українська школа» на період до 2029 року. URL : https://www.kmu.gov.ua/npas/249613934.

5. Саєнко Ю. О. Впровадження технології критичного мислення під час вивчення навчальної дисципліни «Організація екологічного виховання в початковій школі» у майбутніх вчителів початкових класів. Молодий вчений. 2018. № 2(2). С. 640-645. URL : http://nbuv.gov.ua/UJRN/molv_2018_2(2)__48.

6. Формування навичок критичного мислення на уроках іноземної мови : навчально-практичний посібник / О. С. Нікітченко, О. А. Тарасова. Харків : «Друкарня Мадрид», 2017. 104 с. 